\title{
TG/DSC/FTIR/QMS studies on the oxidative decomposition of terpene acrylate homopolymers
}

\author{
Marta Worzakowska ${ }^{1}$
}

Received: 29 April 2016/Accepted: 27 July 2016/Published online: 4 August 2016

(c) The Author(s) 2016. This article is published with open access at Springerlink.com

\begin{abstract}
The oxidative thermal stability along with the identification of the volatile decomposition products under heating of terpene acrylate homopolymers by using TG/ DSC/FTIR/QMS-coupled method was presented. It was found that the decomposition of poly(geranyl acrylate) and poly(neryl acrylate) had quite different course as compared to the decomposition process of poly(citronellyl acrylate) under oxidative conditions. FTIR and QMS analyses confirmed mainly the formation of terpene hydrocarbons, propane, propene, acetic acid, $\mathrm{CO}, \mathrm{CO}_{2}$ and $\mathrm{H}_{2} \mathrm{O}$ as the volatile decomposition products under heating of the hompolymers. The results obtained indicated the complex decomposition process of terpene acrylate homopolymers including the random ester bond scissors, the random main carbon chain scissors, decarboxylation, dehydration and oxidation processes of formed gaseous decomposition products and a residue which led to the full decomposition of homopolymers at ca. $600{ }^{\circ} \mathrm{C}$ under oxidative conditions.
\end{abstract}

Keywords Poly(geranyl acrylate) - Poly(neryl acrylate) Poly(citronellyl acrylate) · TG/DSC/FTIR/QMS

\section{Introduction}

Thermogravimetry-differential scanning calorimetry coupled with Fourier transform infrared spectroscopy and quadrupole mass spectroscopy (TG/DSC/FTIR/QMS) is an

Marta Worzakowska

marta.worzakowska@poczta.umcs.lublin.pl

1 Department of Polymer Chemistry, Faculty of Chemistry, Maria Curie-Skłodowska University, Gliniana 33 Street, 20-614 Lublin, Poland important and often used analysis tool in order to evaluate both thermal stability and the decomposition mechanism of many different structure compounds [1-19]. Many researches and engineers applied this analysis method to their studies because it allowed evaluating not only the thermal resistance of the various materials but also the type of the decomposition gaseous products emitted under heating or burning the materials. In addition by the analysis of the type of the volatile decomposition products emitted under heating of the materials, it is possible to evaluate the decomposition course and the most probable decomposition mechanism of organic, inorganic and polymeric materials. Such knowledge is basic in many practical applications where the materials are subjected to high temperatures [1-19]. Most of the materials which have practical applications are manufactured, utilized and converted under the access of oxygen. As a result, applying the oxidative atmosphere to study the thermal properties of the novel materials is essential from the practical point of view. Meth(acrylate)s are one of the polymer groups which have a wide industrial applications due to their unique properties, among them one can mention their biocompatibility with other polymers, the lack of toxicity, high chemical, hydrolysis, thermal and mechanical resistance. As a result, they are commonly used in many branches of industry as raw materials, components or copolymers in the manufacture of various products using in everyday life $[18,20,21]$. According to the literature survey, the thermal stability and the decomposition course of many meth(acrylate)s [22-27] have been discussed in details. Among the variability of meth(acrylate)s studied, there is no information on the thermal stability and the decomposition path of terpene acrylate hompolymers in the literature data. Due to this, in the present paper the evaluation of the thermal resistance along with the identification of the 
volatile decomposition products under oxidative degradation of three different structure terpene acrylate hompolymers by means of TG/DSC/FTIR/QMS-coupled method has been presented. The terpene acrylate hompolymers under UV-curing process of geranyl acrylate, neryl acrylate and citronellyl acrylate obtained under the reaction of acryloyl chloride and naturally occurring acyclic terpene alcohols such as geraniol, nerol and citronellol were prepared. The effect of the homopolymer structures on the thermal resistance, thermal decomposition course and the thermal degradation mechanism was presented and discussed.

\section{Experimental}

\section{Materials}

The homopolymers: poly(geranyl acrylate), poly(neryl acrylate) and poly (citronellyl acrylate), were obtained under UV-curing process of geranyl acrylate, neryl acrylate and citronellyl acrylate using Irgacure (1mass\%, Fluka) as an initiator and then post-cured at $140{ }^{\circ} \mathrm{C}$ for $6 \mathrm{~h}$. The applied post-cured conditions allowed obtaining the materials with stable, unchanged thermal properties. Chemical structures of homopolymers obtained are given in Scheme 1. The acrylate monomers were prepared in the Department of Polymer Chemistry, UMCS laboratory according to the following procedure: $0.1 \mathrm{~mol}$ of geraniol,

(a)

(a)<smiles>C1CCCCC1</smiles><smiles>C1CCCCC1</smiles><smiles>C/C=C(/C)OC</smiles><smiles>CCC(C)C</smiles><smiles>C1CC2CCCC2C1</smiles>

(b)

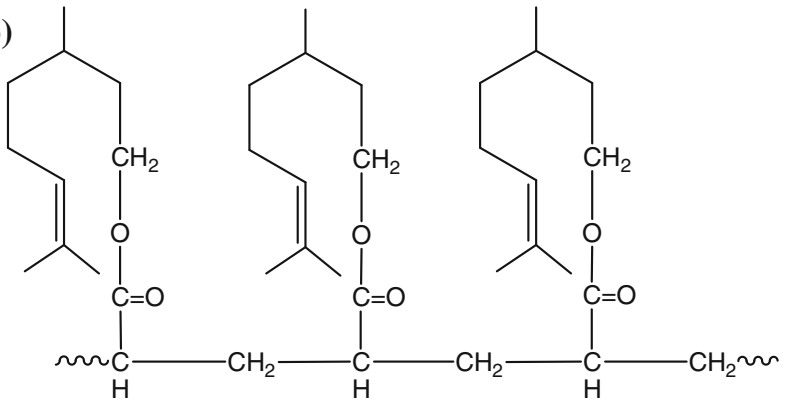

Scheme 1 Chemical structures of homopolymers obtained: a poly(geranyl acrylate) and poly(neryl acrylate) and $\mathbf{b}$ poly(citronellyl acrylate) nerol or citronellol (Fluka) were reacted with $0.12 \mathrm{~mol}$ of acryloyl chloride (Fluka) under $0.12 \mathrm{~mol}$ of triethylamine (Fluka) as a catalyst in the presence of chloroform as a solvent. The reaction was carried out at $5{ }^{\circ} \mathrm{C}$ for $1 \mathrm{~h}$ and then at room temperature for the next $1 \mathrm{~h}$. After completion, the raw product was washed with $1 \% \mathrm{Na}_{2} \mathrm{CO}_{3}, 10 \%$ $\mathrm{HCl}$ and distilled water, dried over $\mathrm{MgSO}_{4}$ and purified using a chromatographic column filled with silica gel (Merck) and chloroform as a solvent [28].

The chemical structures of terpene acrylate monomers by spectroscopic methods such as ATR-FTIR, ${ }^{1}$ HNMR and ${ }^{13}$ CNMR were confirmed.

Geranyl acrylate-formula $\mathrm{C}_{13} \mathrm{H}_{20} \mathrm{O}_{2}:{ }^{1} \mathrm{HNMR}(300 \mathrm{MHz}$, $\left.\mathrm{CDCl}_{3}, \delta \mathrm{ppm}\right)$ : 6.37-6.43 (dd, $\left.1 \mathrm{H}\right), 6.08-6.17(\mathrm{~m}, 1 \mathrm{H})$, 5.79-5.82 (dd, $1 \mathrm{H}), 5.35-5.39(\mathrm{~m}, 1 \mathrm{H}), 5.05-5.10(\mathrm{~m}, 1 \mathrm{H})$, 4.67-4.69 (d, 2H), 2.01-2.12 (m, 4H), $1.72(\mathrm{~s}, 3 \mathrm{H}), 1.68(\mathrm{~s}$, $3 \mathrm{H}), 1.60$ (s, 3H); ${ }^{13} \mathrm{C}-\mathrm{NMR}$ (75 MHz, $\mathrm{CDCl}_{3}, \delta \mathrm{ppm}$ ): 164.40 $(\mathrm{C}=\mathrm{O}), 142.51 \quad(=\mathrm{C}), 131.96(=\mathrm{C}), 130.61 \quad(=\mathrm{CH}), 128.75$ $\left(=\mathrm{CH}_{2}\right), 123.86(=\mathrm{CH}), 118.34(=\mathrm{CH}), 61.58\left(\mathrm{CH}_{2}\right), 39.66$ $\left(\mathrm{CH}_{2}\right), 26.41\left(\mathrm{CH}_{3}\right), 25.79\left(\mathrm{CH}_{2}\right), 17.80\left(\mathrm{CH}_{3}\right), 16.61\left(\mathrm{CH}_{3}\right)$; FTIR (thin film, $\left.\mathrm{cm}^{-1}\right)$ : $3014(\mathrm{v}=\mathrm{C}-\mathrm{H}), 2964(\mathrm{v} \mathrm{C}-\mathrm{H}), 2916(\mathrm{v}$ $\mathrm{C}-\mathrm{H}), 2854$ ( $v \mathrm{C}-\mathrm{H}), 1722$ ( $v \mathrm{C}=\mathrm{O}), 1670(v \mathrm{C}=\mathrm{C}), 1635$ ( $v$ $\mathrm{C}=\mathrm{C}), 1440(\delta \mathrm{C}-\mathrm{H}), 1377(\delta \mathrm{C}-\mathrm{H}), 1263(\mathrm{C}-\mathrm{O}), 1180(v \mathrm{C}-$ O), $977(\gamma=\mathrm{CH}), 956(\gamma=\mathrm{CH}), 808(\gamma=\mathrm{CH}), 754(\gamma=\mathrm{CH})$.

Neryl acrylate-formula $\mathrm{C}_{13} \mathrm{H}_{20} \mathrm{O}_{2}:{ }^{1} \mathrm{HNMR}(300 \mathrm{MHz}$, $\left.\mathrm{CDCl}_{3}, \delta \mathrm{ppm}\right): 6.37-6.43(\mathrm{dd}, 1 \mathrm{H}), 6.08-6.16(\mathrm{~m}, 1 \mathrm{H})$, 5.78-5.82 (dd, $1 \mathrm{H}), 5.36-5.42(\mathrm{~m}, 1 \mathrm{H}), 5.07-5.13(\mathrm{~m}, 1 \mathrm{H})$, 4.64-4.66 (dd, 2H), 2.01-2.17 (m, 4H), 1.77 (d, 3H), 1.68 (s, 3H), 1.60 (s, 3H); ${ }^{13} \mathrm{C}-\mathrm{NMR}\left(75 \mathrm{MHz}, \mathrm{CDCl}_{3}, \delta \mathrm{ppm}\right)$ : $166.35(\mathrm{C}=\mathrm{O}), 142.86(=\mathrm{C}), 132.28(=\mathrm{C}), 130.58(=\mathrm{CH})$, $128.73\left(=\mathrm{CH}_{2}\right), 123.68(=\mathrm{CH}), 119.19(=\mathrm{CH}), 61.27\left(\mathrm{CH}_{2}\right)$, $32.30\left(\mathrm{CH}_{2}\right), 26.75\left(\mathrm{CH}_{3}\right), 25.78\left(\mathrm{CH}_{2}\right), 23.61\left(\mathrm{CH}_{3}\right), 17.75$ $\left(\mathrm{CH}_{3}\right)$; FTIR (thin film, $\left.\mathrm{cm}^{-1}\right): 3015(\mathrm{v}=\mathrm{C}-\mathrm{H}), 2966(v \mathrm{C}-$ $\mathrm{H}), 2916$ ( $v \mathrm{C}-\mathrm{H}), 2856$ ( $v \mathrm{C}-\mathrm{H}), 1722$ ( $v \mathrm{C}=\mathrm{O}), 1670(v$ $\mathrm{C}=\mathrm{C}), 1634(\vee \mathrm{C}=\mathrm{C}), 1441(\delta \mathrm{C}-\mathrm{H}), 1377(\delta \mathrm{C}-\mathrm{H}), 1268$ $(\mathrm{C}-\mathrm{O}), 1182(\nu \mathrm{C}-\mathrm{O}), 980(\gamma=\mathrm{CH}), 959(\gamma=\mathrm{CH}), 808$ $(\gamma=\mathrm{CH}), 754(\gamma=\mathrm{CH})$.

Citronellyl acrylate-formula $\mathrm{C}_{13} \mathrm{H}_{22} \mathrm{O}_{2}: \quad{ }^{1} \mathrm{HNMR}$ (300 MHz, $\left.\quad \mathrm{CDCl}_{3}, \delta \mathrm{ppm}\right): \quad 6.36-6.42 \quad(\mathrm{dd}, \quad 1 \mathrm{H})$, 6.07-6.16 (m, 1H), 5.78-5.83 (dd, 1H), 5.05-5.12 (m, $1 \mathrm{H}), 4.13-4.25(\mathrm{~m}, 2 \mathrm{H}), 1.88-2.05(\mathrm{~m}, 4 \mathrm{H}), 1.68(\mathrm{~s}, 3 \mathrm{H})$, $1.60(\mathrm{~s}, 3 \mathrm{H}), 1.40-1.49(\mathrm{~m}, 2 \mathrm{H}), 1.25-1.55(\mathrm{~m} .1 \mathrm{H})$, 0.92-0.94 (d, 3H); ${ }^{13} \mathrm{C}-\mathrm{NMR}\left(75 \mathrm{MHz}, \mathrm{CDCl}_{3}, \delta \mathrm{ppm}\right)$ : $166.40 \quad(\mathrm{C}=\mathrm{O}), 131.45 \quad(=\mathrm{C}), 130.48 \quad(=\mathrm{CH}), 128.80$ $\left(=\mathrm{CH}_{2}\right), 124.68(=\mathrm{CH}), 63.20\left(\mathrm{CH}_{2}\right), 37.09\left(\mathrm{CH}_{2}\right), 35.50$ $\left(\mathrm{CH}_{2}\right), 29.62(\mathrm{CH}), 25.82\left(\mathrm{CH}_{2}\right), 25.51\left(\mathrm{CH}_{3}\right), 19.55$ $\left(\mathrm{CH}_{3}\right), 17.76\left(\mathrm{CH}_{3}\right)$; FTIR (thin film, $\left.\mathrm{cm}^{-1}\right)$ : $3010(\mathrm{v}=\mathrm{C}-$ $\mathrm{H}), 2958(v \mathrm{C}-\mathrm{H}), 2912(v \mathrm{C}-\mathrm{H}), 2852(v \mathrm{C}-\mathrm{H}), 1724(v$ $\mathrm{C}=\mathrm{O}), 1670(\vee \mathrm{C}=\mathrm{C}), 1631(\vee \mathrm{C}=\mathrm{C}), 1452(\delta \mathrm{C}-\mathrm{H}), 1379$ $(\delta \mathrm{C}-\mathrm{H}), 1260(\mathrm{C}-\mathrm{O}), 1186(v \mathrm{C}-\mathrm{O}), 982(\gamma=\mathrm{CH}), 962$ $(\gamma=\mathrm{CH}), 808(\gamma=\mathrm{CH}), 756(\gamma=\mathrm{CH})$.

The structure of poly(terpene acrylate) homopolymers by ATR-FTIR and ${ }^{13} \mathrm{C} / \mathrm{CP}$ MAS NMR was studied. 
Poly(geranyl acrylate) - formula $\left(\mathrm{C}_{13} \mathrm{H}_{20} \mathrm{O}_{2}\right)_{n}:{ }^{13} \mathrm{C} / \mathrm{CP}$ MAS NMR (75.5 MHz, $\delta \mathrm{ppm}): 175.26(\mathrm{C}=\mathrm{O}), 141.90$ (=C), 131.50 (=C), $124.41(=\mathrm{CH}), 118.47(=\mathrm{CH}), 62.80$ $\left(\mathrm{CH}_{2}\right), 39.79\left(\mathrm{CH}_{2}\right), 37.15\left(\mathrm{CH}_{2}\right), 31.32\left(\mathrm{CH}_{2}\right), 26.10$ $\left(\mathrm{CH}_{3}\right), 24.07\left(\mathrm{CH}_{2}\right), 22.14\left(\mathrm{CH}_{2}\right), 20.55\left(\mathrm{CH}_{2}\right), 17.96$ $\left(\mathrm{CH}_{3}\right), 16.70\left(\mathrm{CH}_{3}\right)$; FTIR (thin film, $\left.\mathrm{cm}^{-1}\right): 2960(v \mathrm{C}-\mathrm{H})$, 2910 ( $v \mathrm{C}-\mathrm{H}), 2852$ ( $v \mathrm{C}-\mathrm{H}), 1728$ ( $v \mathrm{C}=\mathrm{O}), 1667$ ( $\vee \mathrm{C}=\mathrm{C})$, $1442(\delta \mathrm{C}-\mathrm{H}), 1375(\delta \mathrm{C}-\mathrm{H}), 1226(\mathrm{C}-\mathrm{O}), 1159(\mathrm{C}-\mathrm{O})$, $935(\gamma=\mathrm{CH}), 798(\gamma=\mathrm{CH})$.

Poly(neryl acrylate)_formula $\left(\mathrm{C}_{13} \mathrm{H}_{20} \mathrm{O}_{2}\right)_{n}:{ }^{13} \mathrm{C} / \mathrm{CP}$ MAS NMR (75.5 MHz, $\delta \mathrm{ppm}): 174.67(\mathrm{C}=\mathrm{O}), 142.88(=\mathrm{C})$, 133.42 (=C), 124.08 (=CH), $119.40(=\mathrm{CH}), 62.65\left(\mathrm{CH}_{2}\right)$, $38.97\left(\mathrm{CH}_{2}\right), 37.09\left(\mathrm{CH}_{2}\right), 31.87\left(\mathrm{CH}_{2}\right), 29.89\left(\mathrm{CH}_{2}\right), 26.32$ $\left.\left(\mathrm{CH}_{3}\right), 24.23\left(\mathrm{CH}_{2}\right), 21.48\left(\mathrm{CH}_{3}\right), 18.95\left(\mathrm{CH}_{2}\right)\right), 18.01\left(\mathrm{CH}_{3}\right)$.

FTIR (thin film, $\left.\mathrm{cm}^{-1}\right): 2960(v \mathrm{C}-\mathrm{H}), 2914(v \mathrm{C}-\mathrm{H})$, 2852 ( $v \mathrm{C}-\mathrm{H}), 1728(\mathrm{C}=\mathrm{O}), 1670(v \mathrm{C}=\mathrm{C}), 1442(\delta \mathrm{C}-\mathrm{H})$, $1375(\delta \mathrm{C}-\mathrm{H}), 1222(\mathrm{C}-\mathrm{O}), 1155(\mathrm{C}-\mathrm{O}), 935$ ( $\gamma=\mathrm{CH}), 769$ $(\gamma=\mathrm{CH})$.

Poly(citronellyl acrylate)-formula $\left(\mathrm{C}_{13} \mathrm{H}_{22} \mathrm{O}_{2}\right)_{n}:{ }^{13} \mathrm{C} /$ CP MAS NMR (75.5 MHz, $\delta$ ppm): $175.05(\mathrm{C}=\mathrm{O}), 131.39$ (=C), $124.84 \quad(=\mathrm{CH}), 62.9\left(\mathrm{CH}_{2}\right), 38.80\left(\mathrm{CH}_{2}\right), 39.07$ $\left(\mathrm{CH}_{2}\right), 35.77\left(\mathrm{CH}_{2}\right), 31.38\left(\mathrm{CH}_{2}\right), 28.35(\mathrm{CH}), 27.26$ $\left(\mathrm{CH}_{2}\right), 25.99\left(\mathrm{CH}_{3}\right), 23.40\left(\mathrm{CH}_{2}\right), 22.19\left(\mathrm{CH}_{2}\right), 20.16$ $\left(\mathrm{CH}_{3}\right), 18.18\left(\mathrm{CH}_{3}\right)$; FTIR (thin film, $\left.\mathrm{cm}^{-1}\right)$ : $2954(v \mathrm{C}-\mathrm{H})$, 2920 ( $v$ C-H), 2866 ( $v \mathrm{C}-\mathrm{H}), 1724$ ( $v \mathrm{C}=\mathrm{O}), 1665$ ( $v \mathrm{C}=\mathrm{C})$, $1450(\delta \mathrm{C}-\mathrm{H}), 1373(\delta \mathrm{C}-\mathrm{H}), 1257(\mathrm{C}-\mathrm{O}), 1159(\mathrm{C}-\mathrm{O})$, $947(\gamma=\mathrm{CH}), 796(\gamma=\mathrm{CH})$.

\section{Methodology}

The oxidative thermal stability of terpene acrylates was carried out using STA 449 Jupiter F1 (Netzsch, Germany) instrument. The samples were heated from 40 up to $640{ }^{\circ} \mathrm{C}$ with the heating rate of $10{ }^{\circ} \mathrm{C} \mathrm{min}{ }^{-1}$ under oxidative atmosphere (synthetic air, flow rate $100 \mathrm{~mL} \mathrm{~min}^{-1}$ ). The analyses were done in open $\mathrm{Al}_{2} \mathrm{O}_{3}$ crucibles with the sample mass of ca. $10 \mathrm{mg}$. The volatile decomposition products were detected and identified using a FTIR spectrometer TGA 585 (Bruker, Germany) and a QMS 403C spectrometer (Aëolos, Germany) coupling online to STA apparatus. The FTIR spectra were gathered from 600 to $4000 \mathrm{~cm}^{-1}$ with a resolution of $4 \mathrm{~cm}^{-1}$. The QMS spectra were gathered from 10 to $150 \mathrm{amu}$; however, the $\mathrm{m} / \mathrm{z}$ ions higher than 105 were not detected by the spectrometer.

\section{Thermal properties}

According to the data presented in Fig. 1, up to temperature of ca. $200{ }^{\circ} \mathrm{C}$, the homopolymers are thermally stable materials under heating in air conditions. Further heating causes their decomposition which happens at least in main three stages. As it is well visible, the
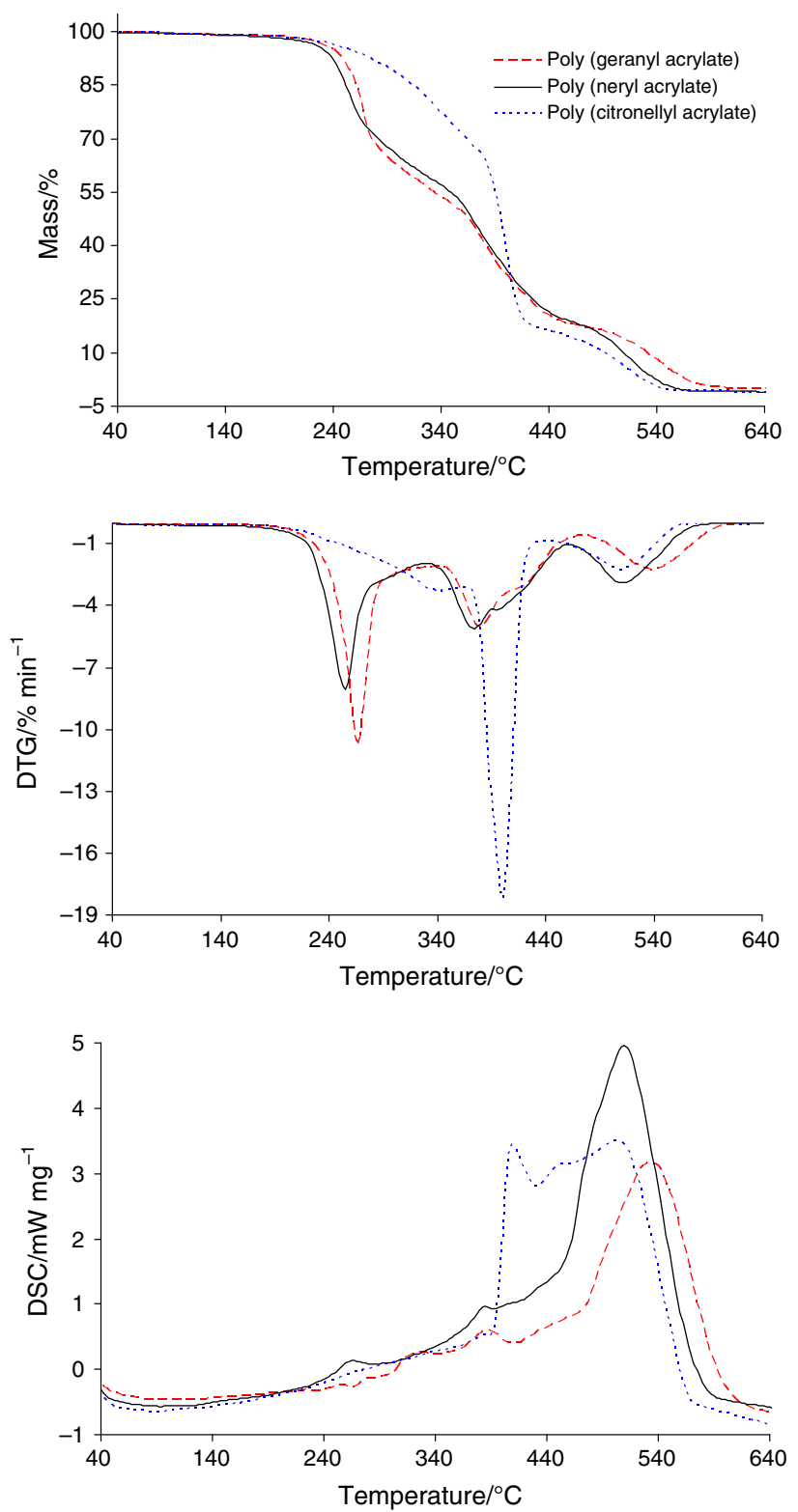

Fig. 1 TG/DTG/DSC curves

homopolymers differ in their initial decomposition temperature (IDT), the temperature of the maximum of mass loss $\left(T_{\max }\right)$ and the mass loss $\left(m_{\text {loss }}\right)$ in each decomposition stage under heating in oxidative conditions. The thermal stability of poly(citronellyl acrylate) described as IDT (5\% of mass loss) was 16 and $23{ }^{\circ} \mathrm{C}$ higher as compared to poly(geranyl acrylate) and poly(neryl acrylate), respectively, as shown in Fig. 1 and Table 1.

Generally, the first and second decomposition stages of terpene acrylate homopolymers are not well separated, but the third decomposition stage is appeared as only one separated stage. The first decomposition stage of poly(geranyl acrylate) from ca. 200 to ca. $340{ }^{\circ} \mathrm{C}$ with $T_{\max 1} 267{ }^{\circ} \mathrm{C}$ and the mass loss $45 \%$ is well visible. The second one which is composed 
Table 1 TG/DTG data in oxidative atmosphere

\begin{tabular}{llllllll}
\hline Homopolymer & IDT $/{ }^{\circ} \mathrm{C}$ & $T_{\max 1} /{ }^{\circ} \mathrm{C}$ & $m_{\text {loss } 1} / \%$ & $T_{\max 2} /{ }^{\circ} \mathrm{C}$ & $m_{\operatorname{loss} 2} / \%$ & $T_{\max 3} /{ }^{\circ} \mathrm{C}$ & $m_{\text {loss } 3} / \%$ \\
\hline Poly(geranyl acrylate) & 239 & 267 & 45.0 & $381 / 420$ & 38.0 & 538 \\
Poly(neryl acrylate) & 232 & 257 & 40.2 & $378 / 400$ & 41.2 & 512 \\
Poly(citronellyl acrylate) & 255 & 343 & 29.4 & 400 & 54.8 & 514 & 18.0 \\
\hline
\end{tabular}

of at least two steps is spread from ca. 340 to ca. $470{ }^{\circ} \mathrm{C}$ with $T_{\max 2} 381$ and $420{ }^{\circ} \mathrm{C}$ and the mass loss $38 \%$. The last third decomposition stage is happened from ca. 470 up to $620{ }^{\circ} \mathrm{C}$ with $T_{\max 3} 538{ }^{\circ} \mathrm{C}$ and the mass loss $17 \%$. It is worth noticing that the decomposition course of poly(neryl acrylate) under oxidative conditions is very similar to the decomposition process of poly(geranyl acrylate). However, small differences in $T_{\max }$ values and the mass loss $\left(m_{\mathrm{loss}}\right)$ values in each stage are appeared. The first decomposition stage from ca. 200 up to $330{ }^{\circ} \mathrm{C}$ with $T_{\max } 257{ }^{\circ} \mathrm{C}$ and the mass loss $40.2 \%$ is observed. The second one is spread from ca. 330 to $460{ }^{\circ} \mathrm{C}$ with $T_{\max 2} 378{ }^{\circ} \mathrm{C} / 400{ }^{\circ} \mathrm{C}$. The third decomposition stage of poly(neryl acrylate) above $460{ }^{\circ} \mathrm{C}$ with $T_{\max 3} 512{ }^{\circ} \mathrm{C}$ and the mass loss $18.6 \%$ is observed. Meanwhile, the decomposition process of poly(citronellyl acrylate) seems to be different as compared to the decomposition course of poly(geranyl acrylate) and poly(neryl acrylate). One can see on TG/DTG curves also three main non-well separated stages; however, the range of the decomposition temperatures and the mass losses in each stage differs considerably when compared to the decomposition path of poly(geranyl and neryl acrylate)s. The first decomposition stage spreads up to temperature of ca. $370{ }^{\circ} \mathrm{C}$ with $T_{\max 1} 343{ }^{\circ} \mathrm{C}$ and the mass loss $29.4 \%$. The second stage happens from ca. 370 up to ca. $430{ }^{\circ} \mathrm{C}$ with $T_{\max 2} 400{ }^{\circ} \mathrm{C}$ and the mass loss $54.8 \%$. The last, third decomposition stage of poly(citronellyl acrylate) is observed between temperatures of ca. 430 and $580{ }^{\circ} \mathrm{C}$ with $T_{\max 3} 514{ }^{\circ} \mathrm{C}$ and the mass loss $15.8 \%$, Table 1 .

When comparing the course of the DSC curves for the homopolymers studied, it is well seen that mainly, non-well separated exothermic effects are appeared in the temperature range where the decomposition processes from the TG/DTG curves are observed. The presence of the exothermic effects on the DSC curves indicates the oxidative decomposition of the materials and chemical reactions which can happen between decomposition products and oxygen [27] leading to the full decomposition of homopolymers at temperatures ca. $600{ }^{\circ} \mathrm{C}$ under oxidative conditions.

\section{Volatile decomposition products}

The identification of the volatile decomposition products was carried out using a FTIR spectrometer and a QMS spectrometer coupling online to STA apparatus. The FTIR spectra of the gaseous decomposition products at IDT, $T_{\max 1}, T_{\max 2}$ and $T_{\max 3}$ were extracted among all collected spectra under analysis. The presented FTIR spectra show strictly all the characteristic absorption bands for the evolved compounds under oxidative decomposition of terpene acrylate homopolymers, as shown in Figs. 2-6.

On the presented FTIR spectra characteristic for poly(geranyl acrylate) and poly(neryl acrylate), as shown in Figs. 2 and 3, one can see that under oxidative decomposition process, firstly and mainly the emission of acyclic or cyclic terpene hydrocarbons is observed [29-35]. It is

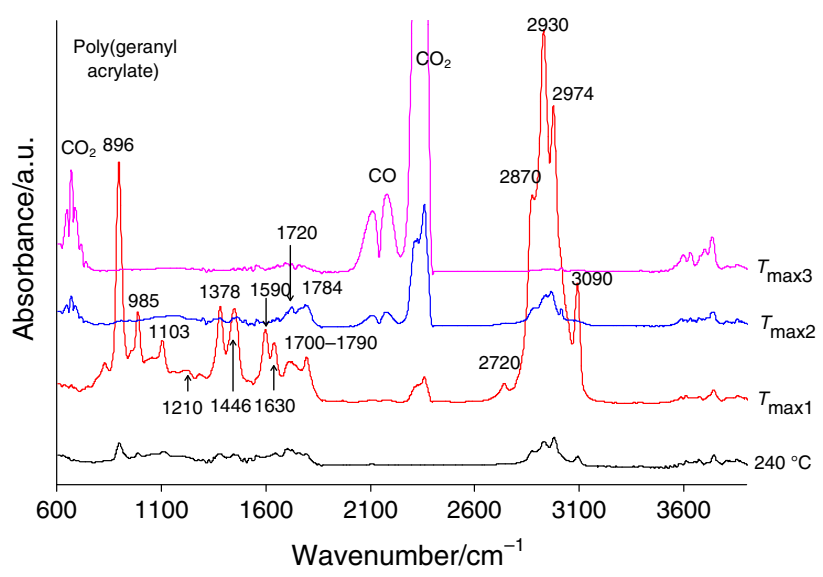

Fig. 2 FTIR spectra of the volatile decomposition products created under heating of poly(geranyl acrylate) in the presence of air

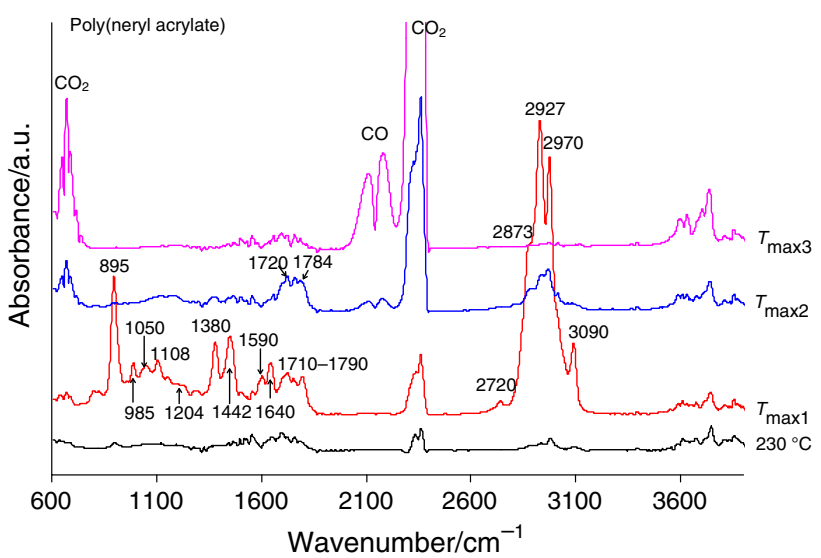

Fig. 3 FTIR spectra of the volatile decomposition products created under heating of poly(neryl acrylate) in the presence of air 
Fig. 4 QMS spectra of the volatile decomposition products formed under heating of poly(geranyl acrylate) in air
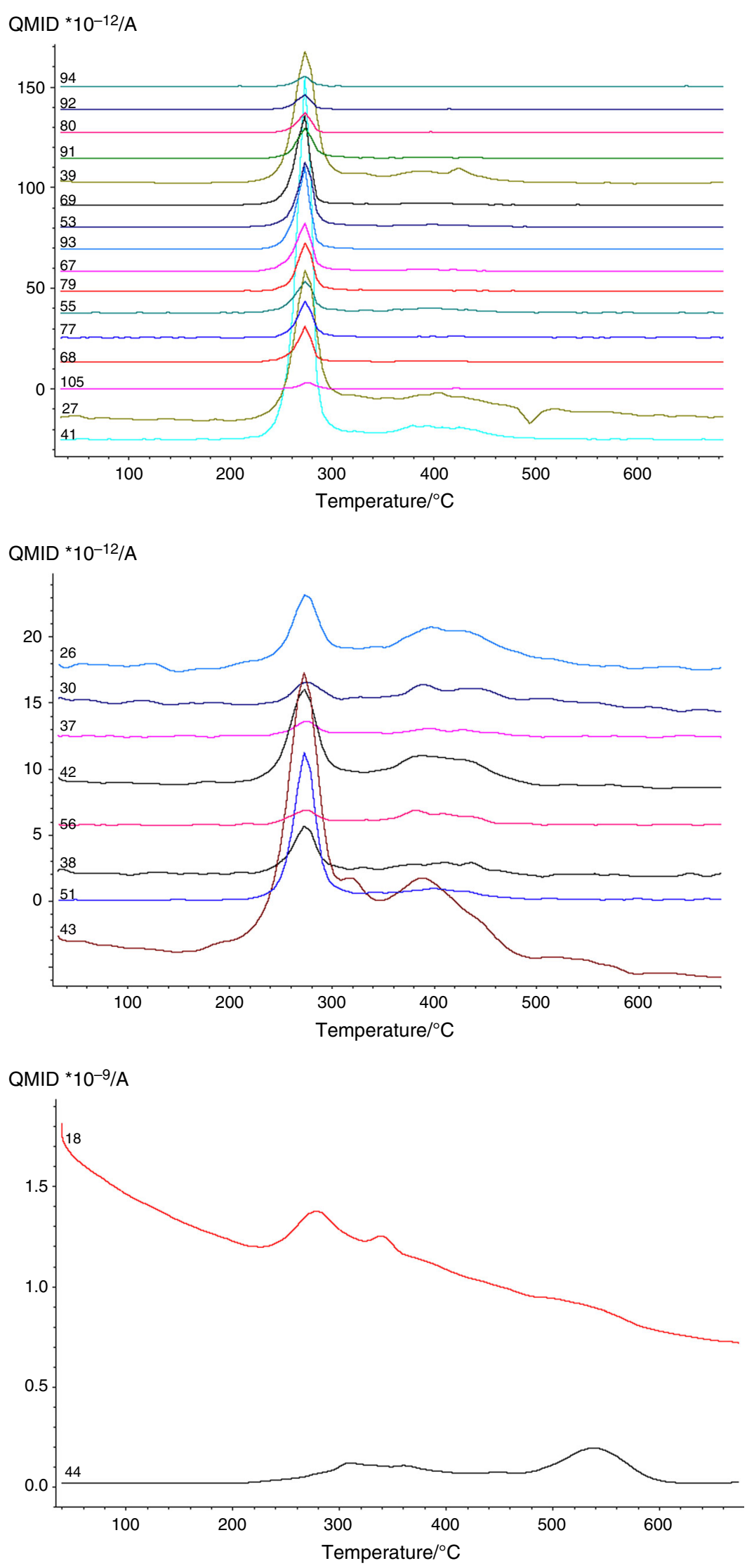
Fig. 5 QMS spectra of the volatile decomposition products formed under heating of poly(neryl acrylate) in air

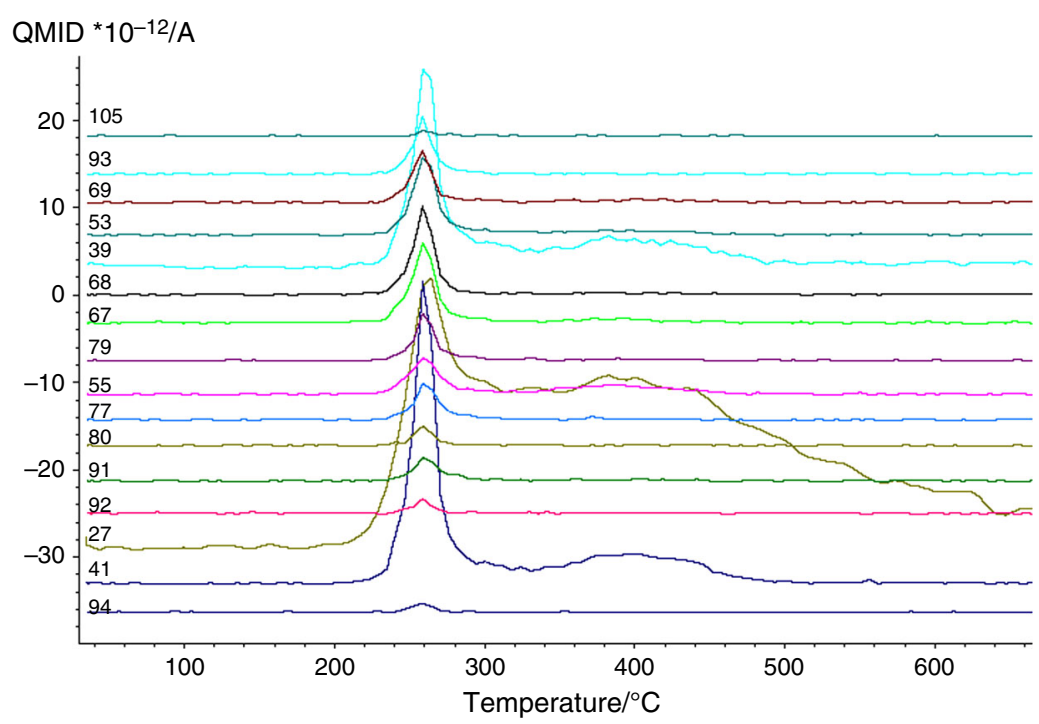

QMID * $10^{-12} / \mathrm{A}$
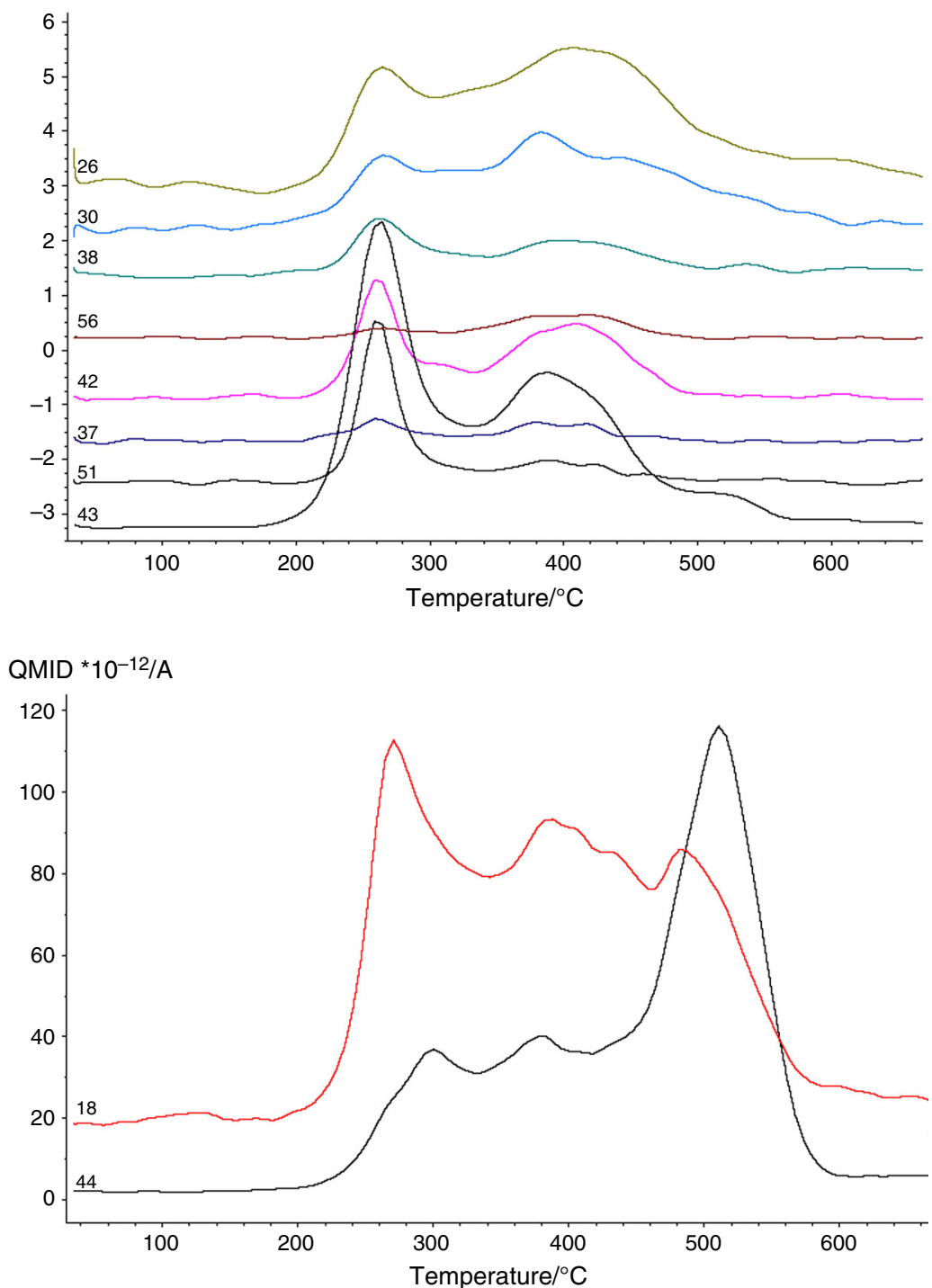


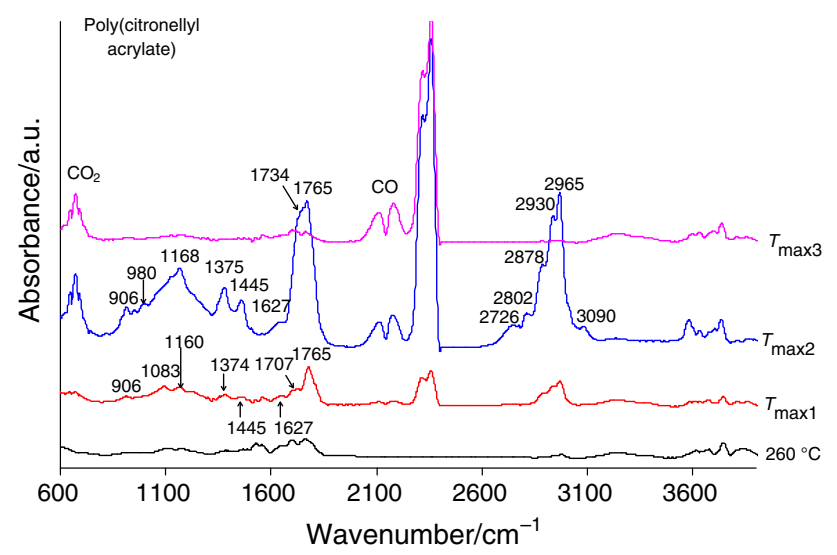

Fig. 6 FTIR spectra of the gaseous decomposition products emitted under heating of poly(citronellyl acrylate) in air

confirmed by the presence of the characteristic bands for $\mathrm{CH}_{3}$ and $-\mathrm{CH}_{2-}$ at $1378-1446 \mathrm{~cm}^{-1}$ (the deformation vibrations) and at $2870-2974 \mathrm{~cm}^{-1}$ (the stretching vibrations) and the presence of absorption bands for carboncarbon double bonds at $895-985 \mathrm{~cm}^{-1}$ (the out-of-plane deformation vibrations of $=\mathrm{C}-\mathrm{H}$ groups), at $1590-1640 \mathrm{~cm}^{-1}$ (the stretching vibrations of $\mathrm{C}=\mathrm{C}$ ), and the bands centered at $3090 \mathrm{~cm}^{-1}$ (the stretching vibrations of $=\mathrm{C}-\mathrm{H}$ ) [29-35]. In addition, the creation of other terpene derivatives containing oxygen functional groups at the first decomposition stage was expected due to the presence of the bands at $1700-1790 \mathrm{~cm}^{-1}$ (the stretching vibrations of carbonyl groups), the bands from 1050 up to $1210 \mathrm{~cm}^{-1}$ (the stretching vibrations of $\mathrm{C}-\mathrm{O}$ ), the band at $2720 \mathrm{~cm}^{-1}$ (the stretching vibrations of $\mathrm{C}-\mathrm{H}$ in aldehyde groups) and the bands above $3500 \mathrm{~cm}^{-1}$ (the stretching vibrations of $\mathrm{OH})$ on the FTIR spectra. It indicates the formation of acids and aldehydes under oxidative decomposition of poly(geranyl acrylate) and poly(neryl acrylate) homopolymers. In addition, the presence of the bands at $1050-1210 \mathrm{~cm}^{-1}$ and the signals above $3500 \mathrm{~cm}^{-1}$ may indicate also the creation of terpene alcohols at $T_{\max 1}$ [29-35]. However, it might be suspected that the formed alcohols and aldehydes can undergo the partial oxidation process to the corresponding acids under the presence of air. The decarboxylation process of formed acids leads to the formation of terpene hydrocarbons and $\mathrm{CO}_{2}$ at $T_{\max 1}$. Regarding the structure of geranyl and neryl acrylate homopolymers and the presence of the characteristic absorption bands on the FTIR spectra, mainly the random ester bond scissors in side chains connected with the partial oxidation of formed decomposition products and thus decarboxylation reactions can be the main processes which may happen up to temperature of ca. $370{ }^{\circ} \mathrm{C}$.

The FTIR spectrum for geranyl and neryl acrylate homopolymers obtained at $T_{\max 2}$ generally shows lower emission of the decomposition gaseous products as compared to the emission at $T_{\max 1}$. However, the presence of the stretching vibrations characteristic for carbonyl groups $\left(1720-1784 \mathrm{~cm}^{-1}\right)$, the stretching vibrations of $\mathrm{C}-\mathrm{H}$ groups (2870-2990 $\mathrm{cm}^{-1}$ ) and the stretching vibrations of $\mathrm{C}-\mathrm{H}\left(1360-1463 \mathrm{~cm}^{-1}\right)$ is precisely observed. It may indicate the formation of the fragments containing oxygen groups as well as alkane and alkene fragments. Besides those organic species, the presence of $\mathrm{CO}$ (2110-2184 $\left.\mathrm{cm}^{-1}\right), \mathrm{CO}_{2}$ (699 and 2329-2358 $\mathrm{cm}^{-1}$ ) and the stretching vibrations of -OH groups above $3500 \mathrm{~cm}^{-1}$ as a result of decarboxylation and dehydration of a residue formed after the first decomposition stage and it partial depolymerization and oxidation which leading to the formation of carbonaceous residue was observed. As the temperature is higher than ca. $440{ }^{\circ} \mathrm{C}$, the beginning of the third decomposition stage and the emission mainly of $\mathrm{CO}$ (2110-2184 $\left.\mathrm{cm}^{-1}\right), \mathrm{CO}_{2}\left(699\right.$ and $\left.2329-2358 \mathrm{~cm}^{-1}\right)$ and water vapor (above $3500 \mathrm{~cm}^{-1}$ ) [31, 32] are well indicated. The type of the gaseous decomposition products confirms the oxidation reactions of a char residue formed after the second decomposition stage resulting in the total decomposition of the materials studied. Additionally performed QMS analysis allowed describing more precisely the type of the volatile decomposition products emitted in each decomposition stage. The QMS spectra of the volatile decomposition products emitted under heating of poly(geranyl acrylate) and poly(neryl acrylate) are presented in Figs. 4 and 5. In addition, the most probable decomposition products with characteristic $\mathrm{m} / \mathrm{z}$, values [36] are given in Table 2. According to the QMS results, one can clearly see the presence of the $\mathrm{m} / \mathrm{z}$ ions characteristic for geraniol or nerol, myrcene, limonene, citral, geranic acid and 2,6-dimethylhepta-1,5-diene at $T_{\max 1}$. However, at $T_{\max 1}$ also the formation of other organic gaseous species is detected. It is confirmed by the presence of $\mathrm{m} / \mathrm{z}$ ions 26,30 , $37,38,42,43,51$ and 56 which can be due to the creation of alkenes, alkanes and organic acid as a result of the scissions of the $\mathrm{C}-\mathrm{C}$ bonds in the main polymer chain. However as the temperature is growing above $340{ }^{\circ} \mathrm{C}$, the $\mathrm{m} / \mathrm{z}$ ions such as $26,27,30,37,38,39,41,42,43,51,55$ and 56 are detected by QMS spectrometer. Their presence may indicate the further secondary reactions like decarboxylation, dehydration and oxidation of the previously formed gaseous organic species leading to the creation of secondary volatile decomposition products such as alkanes, alkenes, organic acids and $\mathrm{CO}, \mathrm{CO}_{2}$ and $\mathrm{H}_{2} \mathrm{O}$ at $T_{\max 2}$. Further heating of the materials above temperature of $470{ }^{\circ} \mathrm{C}$ caused only the creation of inorganic volatile products such as $\mathrm{CO}, \mathrm{CO}_{2}$ and $\mathrm{H}_{2} \mathrm{O}$, as shown in Figs. 4 and 5 [36]. The results confirmed the observations made based on the FTIR spectra where terpene hydrocarbons, alkanes, alkenes and organic acid were the main 
Table 2 The main organic volatile decomposition products and the corresponding $\mathrm{m} / \mathrm{z}$, ion values with relative intensity regarding the NIST database [36]

\begin{tabular}{|c|c|c|}
\hline Homopolymer & $\begin{array}{l}\text { Volatile decomposition } \\
\text { products }\end{array}$ & $\mathrm{m} / \mathrm{z}$, values (relative intensity) \\
\hline \multirow[t]{10}{*}{$\begin{array}{l}\text { Poly(geranyl acrylate) and poly } \\
\text { (neryl acrylate) }\end{array}$} & Geraniol/nerol & $\begin{array}{l}\text { 69(100), 41(60), 68(21,4), 67(15,6), 93(14,3), 39(13,9), 123(13,8), } \\
\text { 53((11,2), 55(9,6), 84(9) }\end{array}$ \\
\hline & Myrcene & $\begin{array}{l}41(100), 93(85,5), 69(79,6), 39(29,9), 27(28), 53(14,1), 79(13,8), \\
\quad 67(11), 77(11), 91(9,5)\end{array}$ \\
\hline & Ocimene & $\begin{array}{l}93(100), 91(50), 79(45,2), 80(36,6), 77(36,5), 41(31,7), 92(24,9), \\
39(23,2), 53(21,1), 105(18,4)\end{array}$ \\
\hline & Limonene & $\begin{array}{l}68(100), 93(39,7), 39(32,2), 67(31,8), 41(28,3), 27(26,6), 53(23,2), \\
\quad 79(17,7), 94(13,1), 92(11,4)\end{array}$ \\
\hline & Citral & $\begin{array}{l}69(100), 41(74,6), 84(26,7), 39(25,5), 94(16,2), 53(13,1), 83(12,5), \\
\quad 67(10,5), 109(9,4), 91(8,9)\end{array}$ \\
\hline & Geranic acid & $\begin{array}{l}69(100), 41(68,2), 100(15,2), 39(12,4), 123(7,7), 53(6,7), 43(6), 82(5,7), \\
\quad 70(5,5), 67(4,6)\end{array}$ \\
\hline & 2,6-Dimethylhepta-1,5-diene & $\begin{array}{l}69(100), 41(55,3), 81(34,5), 67(30,5), 39(20,8),(20) 27(19,8), 80(18), \\
53(16), 68(15), 29(13,2)\end{array}$ \\
\hline & Propene & $\begin{array}{l}41(100), 39(72,5), 42(70,3), 27(38,7), 40(29,1), 38(19,4), 37(12,7), \\
26(10,5), 15(5,5), 14(3,4)\end{array}$ \\
\hline & Propane & $\begin{array}{l}29(100), 28(58,7), 27(41,9), 44(27,4), 43(23,1), 39(18,9), 41(13,4), \\
26(9,1), 15(7,2), 42(6)\end{array}$ \\
\hline & Acetic acid & $\begin{array}{l}43(100), 45(90,3), 60(74,7), 15(17), 42(13), 29(8,4), 14(4,8), 28(4), \\
\quad 41(3,5), 18(2,7)\end{array}$ \\
\hline \multirow[t]{10}{*}{ Poly(citronellyl acrylate) } & Citronellol & $\begin{array}{l}71(100), 68(38,1), 41(36), 69(31,5), 43(28,2), 55(27,9), 81(24,3) \\
56(20,2), 57(20), 67(20)\end{array}$ \\
\hline & Rhodinal & $\begin{array}{l}41(100), 69(98,9), 55(62), 95(52,7), 67(36,8), 56(33,4), 112(28,6), \\
\quad 121(27,5), 111(24,1), 39(23,4)\end{array}$ \\
\hline & $\begin{array}{l}\text { Cyclohexane-1-methyl-4-(1- } \\
\text { methylethenyl) }\end{array}$ & $\begin{array}{l}\text { 81(100), 95(91), 68(76), 67(69), 55(63), 41(53), 82(46), 96(44), 138(27), } \\
\quad 69(24)\end{array}$ \\
\hline & 2-Octene-2,6-dimethyl & $\begin{array}{l}\text { 69(100), 70(72,8), 41(53,5), 55(51,4), 56(41,8), 140(36), 43(24,9), } \\
57(22), 83(21,7), 84(18,3)\end{array}$ \\
\hline & Citronellic acid & $\begin{array}{l}69(100), 41(68,8), 55(56,5), 95(55,7), 110(49,6), 56(31,6), 70(22,1) \\
\quad 67(20,5), 39(18,1), 82(15,2)\end{array}$ \\
\hline & 2-Heptene-2,6-dimethyl & $\begin{array}{l}41(100), 69(67,5), 56(66,1), 55(48), 39(23,8), 70(21,9), 43(17,7) \\
27(17,5), 57(16,8), 29(15,3)\end{array}$ \\
\hline & 3,7-Dimethyl-1,6-octadiene & $\begin{array}{l}41(100), 39(69,3), 67(41,4), 55(39,6), 81(28,6), 53(28,4), 82(12,5), \\
\quad 69(11,3), 40(10,3), 65(9,6)\end{array}$ \\
\hline & Propene & $\begin{array}{l}41(100), 39(72,5), 42(70,3), 27(38,7), 40(29,1), 38(19,4), 37(12,7), \\
26(10,5), 15(5,5), 14(3,4)\end{array}$ \\
\hline & Propane & $\begin{array}{l}29(100), 28(58,7), 27(41,9), 44(27,4), 43(23,1), 39(18,9), 41(13,4), \\
26(9,1), 15(7,2), 42(6)\end{array}$ \\
\hline & Acetic acid & $\begin{array}{l}43(100), 45(90,3), 60(74,7), 15(17), 42(13), 29(8,4), 14(4,8), 28(4), \\
\quad 41(3,5), 18(2,7)\end{array}$ \\
\hline
\end{tabular}

decomposition products under heating of poly(geranyl acrylate) and poly (neryl acrylate) in the presence of air.

It is worth noticing that the decomposition process of citronellyl acrylate homopolymer has a completely different course. The first decomposition stage is connected with lower mass loss and thus with lower emission of the gaseous decomposition products as compared to those observed for geranyl and neryl acrylate homopolymers. One can see the presence of the characteristic absorption bands for terpene derivatives at $T_{\max 1}$ on the FTIR spectra, as shown in Fig. 6 [37]. However, the intensity of the absorption bands was lower at $T_{\max 1}$ than at $T_{\max 2}$. At $T_{\max 1}$, the presence of the signals responsible for the deformation vibrations of $\mathrm{C}-\mathrm{H}$ (1374 and $1445 \mathrm{~cm}^{-1}$ ), the stretching vibrations of $\mathrm{C}-\mathrm{H}$ (2880-2970 $\left.\mathrm{cm}^{-1}\right)$, the out-of-plane deformation vibrations of $=\mathrm{C}-\mathrm{H}\left(906 \mathrm{~cm}^{-1}\right)$, the stretching vibration of $\mathrm{C}=\mathrm{C}$ $\left(1627 \mathrm{~cm}^{-1}\right)$, the stretching vibrations of $\mathrm{C}=\mathrm{O}$ (1707-1765 $\mathrm{cm}^{-1}$ ) and the stretching vibrations of $\mathrm{C}-\mathrm{O}$ 
Fig. 7 QMS spectra of the volatile decomposition products formed under heating of poly(citronellyl acrylate) in air
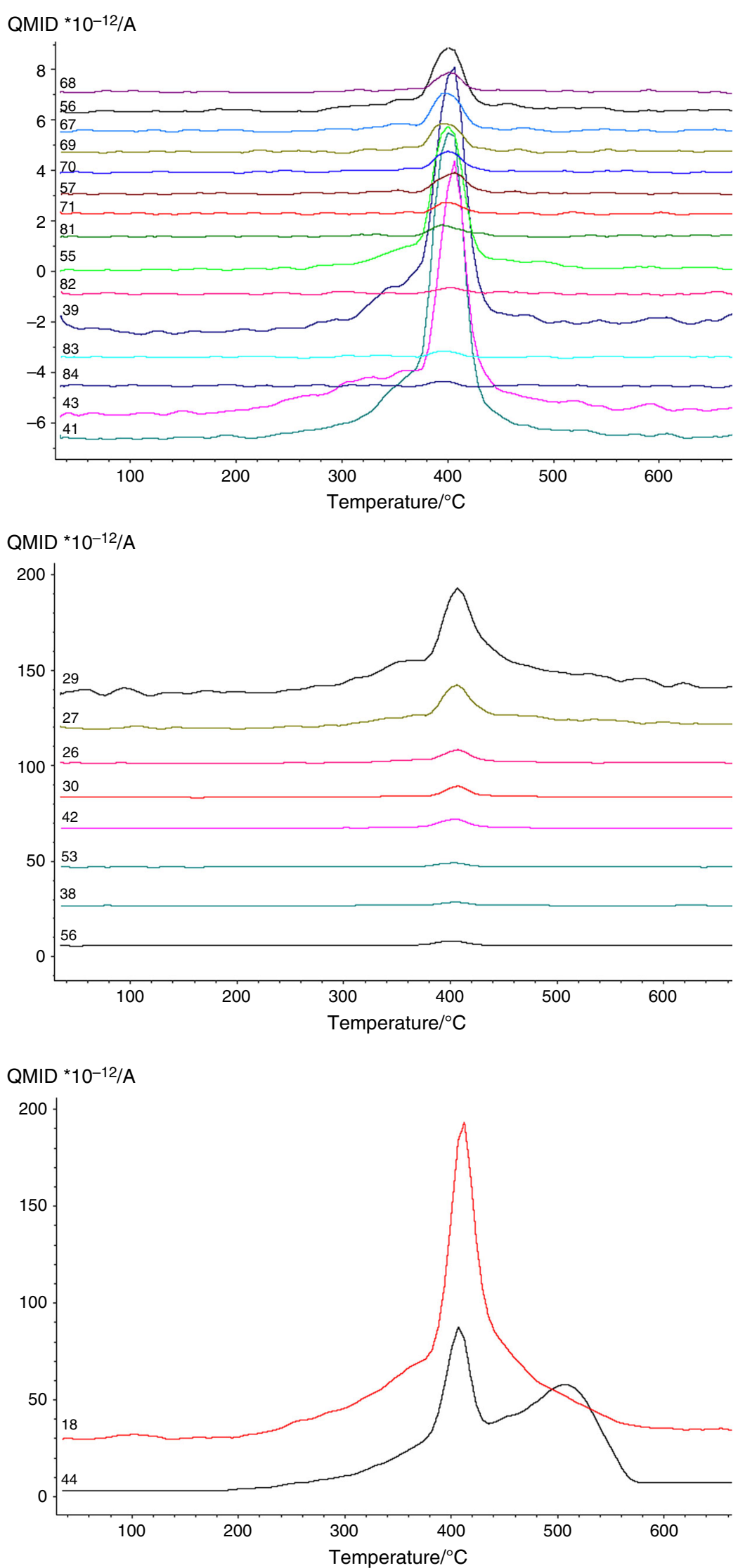
(1083-1205 $\mathrm{cm}^{-1}$ ) indicates the formation of terpene derivatives as primary decomposition products [31, 32, 37] which is a similar behavior to those observed for the decomposition process of geranyl and neryl acrylate homopolymers. But, lower mass loss at this stage and lower intensity in the emission of the decomposition gaseous products may indicate only on the breaking of the $\mathrm{C}-\mathrm{O}$ bonds between main carbon chain and the branching initiated on the end polymer chains [22] and the partial oxidation and decarboxylation of formed species leading to the emission of $\mathrm{CO}\left(2110-2184 \mathrm{~cm}^{-1}\right), \mathrm{CO}_{2}$ (699 and 2329-2358 $\left.\mathrm{cm}^{-1}\right)$ and $\mathrm{H}_{2} \mathrm{O}$ (above $3500 \mathrm{~cm}^{-1}$ ) [31, 32]. As the temperature is increased, the emission of the gaseous decomposition products under heating of citronellyl acrylate homopolymer drastically increased, reaching it maximum at $T_{\max 2}$. At this temperature, the absorption signals characteristic for the outof-plane deformation vibrations of $=\mathrm{C}-\mathrm{H}\left(906-980 \mathrm{~cm}^{-1}\right)$, the deformation vibrations of $\mathrm{C}-\mathrm{H}\left(1374-1445 \mathrm{~cm}^{-1}\right)$, the stretching vibrations of C-H (2802-2965 $\left.\mathrm{cm}^{-1}\right)$, the stretching vibrations of $=\mathrm{C}-\mathrm{H}\left(3090 \mathrm{~cm}^{-1}\right)$, the stretching vibrations of $\mathrm{C}=\mathrm{O}\left(1734-1765 \mathrm{~cm}^{-1}\right)$, the stretching vibrations of $\mathrm{C}-\mathrm{O}$ (wide signal with maximum at $1168 \mathrm{~cm}^{-1}$ ) and also the presence of $\mathrm{CO}, \mathrm{CO}_{2}$ and $\mathrm{H}_{2} \mathrm{O}[31,32]$ clearly confirmed that the main decomposition stage of citronellyl acrylate homopolymer happened at temperatures higher than $370{ }^{\circ} \mathrm{C}$ in oxidative atmosphere. This decomposition stage is connected with the simultaneous reactions including the breaking of the main carbon chain and terpene branching, decarboxylation, dehydration and oxidation processes of the gaseous decomposition products and a residue. It results in the creation of the complex organic volatile products; among them, the most expected are terpene derivatives such as alkenes, aldehydes, alcohols and acids [36] and their further partial oxidation and thus the formation of the decomposition products such as alkanes, alkenes, $\mathrm{CO}, \mathrm{CO}_{2}$ and $\mathrm{H}_{2} \mathrm{O}$, as shown in Fig. 6. Finally at temperatures higher than $440{ }^{\circ} \mathrm{C}$, the resulted carbonaceous residue undergoes oxidation processes and thus the emission of only $\mathrm{CO}, \mathrm{CO}_{2}$ and $\mathrm{H}_{2} \mathrm{O}$. The FTIR results were confirmed by the QMS analysis. The clear presence of $\mathrm{m} / \mathrm{z}$ ions responsible for the emission of terpene hydrocarbons such as citronellol, rhodinal, cyclohexane-1methyl-4-(1-methylethenyl), 2-octene-2,6-dimethyl, citronellic acid, 2-heptene-2,6-dimethyl, 3,7-dimethyl-1,6-octadiene and secondary decomposition products: alkanes, alkenes, organic acids, $\mathrm{CO}, \mathrm{CO}_{2}$ and $\mathrm{H}_{2} \mathrm{O}[31,32]$ at $T_{\max 2}$, was observed, as shown in Fig. 7 and Table 2.

\section{Conclusions}

The TG/DSC/FTIR/QMS-coupled method was applied to study the thermal behavior and the decomposition mechanism under oxidative conditions of terpene acrylate homopolymers which differed in their structure. The thermal resistance of homopolymers and their decomposition course was quite different. The poly(citronellyl acrylate) homopolymer was more thermally stable as compared to poly(geranyl acrylate) and poly (neryl acrylate) homopolymers. All the materials studied decomposed at least in three main stages connected with the releasing of the mixture of organic and inorganic volatile components. Generally, chemical composition of the gaseous products emitted under heating of homopolymers in air atmosphere consisted of terpene hydrocarbons, some other lower mass alkene, alkane and organic acid species, $\mathrm{CO}_{2}, \mathrm{CO}$ and $\mathrm{H}_{2} \mathrm{O}$. The results proved that the decomposition mechanism of homopolymers studied was complex, and it was associated with different decomposition processes such as random ester bond scissors in side chains, random main chain scissors, oxidation, dehydration and decarboxylation processes under the conditions applied.

Open Access This article is distributed under the terms of the Creative Commons Attribution 4.0 International License (http://crea tivecommons.org/licenses/by/4.0/), which permits unrestricted use, distribution, and reproduction in any medium, provided you give appropriate credit to the original author(s) and the source, provide a link to the Creative Commons license, and indicate if changes were made.

\section{References}

1. Yang J, Chen H, Zhao W, Zhou J. Combustion kinetics and emission characteristics of peat by using TG-FTIR technique. J Therm Anal Calorim. 2016;124:519-28.

2. Zapała L, Kosińska M, Woźnicka E, Byczyński Ł, Zapała W. Synthesis, spectral and thermal study of La(III), Nd(III), Sm(III), $\mathrm{Eu}(\mathrm{III}), \mathrm{Gd}(\mathrm{III})$ and $\mathrm{Tb}(\mathrm{III})$ complexes with mefenamic amid. J Therm Anal Calorim. 2016;124:363-74.

3. Chen X, Liu L, Zhuo J, Ciao C. Influence of iron oxide green on smoke suppression properties and combustion behavior of intumescent flame retardant epoxy composites. J Therm Anal Calorim. 2015;119:625-33.

4. Wu W, Lv S, Liu X, Qu H, Zhang H, Xu J. Using TG-FTIR and TG-MS to study thermal degradation of metal hypophosphites. J Therm Anal Calorim. 2014;118:1569-75.

5. Xiao X, Hu S, Zhai J, Chen T, Mai Y. Thermal properties and combustion behaviors of flame-retarded glass fiber-reinforced polyamide 6 with piperazine pyrophosphate and aluminum hypophosphite. J Therm Anal Calorim. 2016;. doi:10.1007/ s10973-016-5391-0.

6. Mustata F, Tudorachi N. Thermal behavior of epoxy resin cured with aromatic dicarboxylic acids. J Therm Anal Calorim. 2016; doi:10.1007/s10973-016-5374-1.

7. Fuliaş A, Vlase G, Şoica C, Bercean V, Vlase T, Ledeţi I. Thermal behaviour of a modified encapsulation agent, Heptakis6-iodo-6-deoxy-beta-cyclodextrin. J Therm Anal Calorim. 2014;118:961-6.

8. Gallo RC, Ferreira APG, Castro REA, Cavalheiro ETG. Studying the thermal decomposition of carvedilol by coupled TG-FTIR. J Therm Anal Calorim. 2016;123:2307-12. 
9. Chen X, Song W, Liu J, Jiao C, Qian Y. Synergistic flame-retardant effects between aluminum hypophosphite and expandable graphite in silicone rubber composites. J Therm Anal Calorim. 2015;120:1819-26.

10. Luo F, Wu K, Lu M, Nie S, Li X, Guan X. Thermal degradation and flame retardancy of microencapsulated ammonium polyphosphate in rigid polyurethane foam. J Therm Anal Calorim. 2015;120:1327-35.

11. Bartyzel A, Sztance M, Sztanke K. Thermal studies of analgesic active 8-aryl-2,6,7,8-tetrahydroimidazo[2,1-c][1,2,4]triazine-3,4diones. J Therm Anal Calorim. 2016;123:2053-60.

12. Amorim PHO, Garcia Ferreira AP, Machado LCM, Cervini P, Gomes Cavalheiro ET. Investigation on the thermal behavior of $\beta$-blockers antihypertensives atenolol and nadolol using TG/DTG, DTA, DSC, and TG-FTIR. J Therm Anal Calorim. 2015;120:1035-42.

13. Surender R, Mahendran AR, Wuzella G, Vijayakumar CT. Synthesis, characterization and degradation behavior of thermoplastic polyurethane from hydroxylated hemp seed oil. J Therm Anal Calorim. 2016;123:525-33.

14. Jia P, Hu L, Zhang M, Zhou Y-H. TG-FTIR and TG-MS analysis applied to study the flame retardancy of PVC-castor oil-based chlorinated phosphate ester blends. J Therm Anal Calorim. 2016; doi:10.1007/s10973-015-5199-3.

15. Mello GS, Cardoso AP, Oliveira WERS, Siqueira AB. Tryptophan, a proposal of the mechanism of thermal decomposition. J Therm Anal Calorim. 2015;122(1394):1401.

16. Ghezzi L, Duce C, Bernazzani L, Bramanti E, Colombini MP, Tiné MR, Bonaduce I. Interactions between inorganic pigments and rabbit skin glue in reference paint reconstructions. J Therm Anal Calorim. 2015;122:315-22.

17. Apostolopoulou A, Nagygyörgy V, Madarász J, Stathatos E, Pokol G. Thermal stability and electrical studies on hybrid and composite sol-gel quasi-solid-state electrolytes for dye-sensitized solar cells. J Therm Anal Calorim. 2015;121:371-80.

18. Grochowicz M. Investigation of the thermal behavior of 4-vinylpyridine-trimethylolpropane trimethacrylate copolymeric microspheres. J Therm Anal Calorim. 2014;118:1603-11.

19. Grochowicz M, Kierys A. Thermal characterization of polymersilica composites loaded with ibuprofen sodium salt. J Anal Appl Pyrol. 2015;114:91-9.

20. Pethrick RA, Zaikov GE, Horák D, editors. Polymers and composites. Synthesis, properties and applications. New York: New Science Publisher; 2007.
21. Saunders KJ. Acrylic polymers. Organic polymer chemistry. 2nd ed. Berlin: Springer; 1988.

22. Bertini F, Audiso G, Zuev VV. Investigation of the thermal degradation of poly- $n$-alkyl acrylates and poly- $n$-alkyl methacrylate (C1-C12). Polym Degrad Stab. 2005;89:2-239.

23. Cameron GG, Kane DR. The thermal degradation of poly(methyl acrylate). J Polym Sci B. 1964;2:693-6.

24. Grassie N, Speakman JG. Thermal degradation of poly(alkyl acrylates). I. Preliminary investigations. J Polym Sci A-1. 1971;9:919-29.

25. Grassie N, Speakman JG, Davis TI. Thermal degradation of poly(alkylacrylates). II. Primary esters: ethyl, $n$-propyl, $n$-Butyl, and 2-ethylhexyl. J Polym Sci A-1. 1971;9:931-48.

26. Gunawan L, Haken JK. The mechanisms of thermal degradation of poly(methyl acrylate) using pyrolysis gas chromatography mass spectrometry. J Polym Sci Polym Chem Ed. 1985;23:2539.

27. Pielichowski K, Njuguna J, editors. Thermal degradation of polymeric materials. Brussels: Rapra Technology Limited; 2005.

28. Grochowicz M, Gawdzik B. Preparation and characterization of porous crosslinked microspheres of new aromatic methacrylates. J Porous Mater. 2013;20:339-49.

29. Worzakowska M. TG/FTIR/QMS studies of long chain esters of geraniol. J Anal Appl Pyrol. 2014;110:181-93.

30. Worzakowska M, Ścigalski P. Synthesis and thermal behavior of linear neryl diesters in inert and oxidative atmosphere. J Therm Anal Calorim. 2014;115:783-92.

31. Sokrates G. Infrared and Raman characteristic group frequencies, tables and charts. New York: Wiley; 2001.

32. NIST chemistry webbook, NIST standard reference data. 2011. http://webbook.nist.gov.

33. Worzakowska M. Synthesis, characterization and thermal properties of new flavor compounds. J Therm Anal Calorim. 2014;116:727-36.

34. Worzakowska M, Ścigalski P. TG/DSC/FTIR characterization of linear geranyl diesters. J Therm Anal Calorim. 2013;113:53-60.

35. Worzakowska M. Thermal properties of neryl long-chain esters obtained under microwave irradiation. J Therm Anal Calorim. 2015;120:1715-22.

36. NIST chemistry webbook standard reference database number 69 . 2011. http://webbook.nist.gov/chemistry.

37. Worzakowska M. Thermal properties of citronellyl diesters. J Therm Anal Calorim. 2014;118:299-309. 